\title{
MANUFACTURING LARGE-SIZED BEDS BY CONSUMABLE-NOZZLE ELECTROSLAG WELDING
}

\author{
K.P. SHAPOVALOV $^{1}$, V.A. BELINSKY ${ }^{1}$, S.N. KOSINOV $^{1}$, S.N. LITVINENKO ${ }^{1}$, \\ K.A. YUSHCHENKO ${ }^{2}$, I.I. LYCHKO ${ }^{2}$ and S.M. KOZULIN ${ }^{2}$ \\ ${ }^{1}$ Company «NKMZ» \\ 4 Ordzhonikidzhe Str., Kramatorsk, Donetsk reg., Ukraine \\ ${ }^{2}$ E.O. Paton Electric Welding Institute, NASU \\ 11 Bozhenko Str., 03680, Kiev, Ukraine. E-mail: office@paton.kiev.ua
}

\begin{abstract}
PWI in collaboration with Novo-Kramatorsk Machine-Building Works (NKMZ company) continues improving electroslag welding technology. This work provides a description of the technology of consumablenozzle electroslag welding in manufacture of large-sized beds with butts of $420-460 \times 2200-2380$ and 940-1120 × 1040-1250 mm cross-section. Machine time shortening almost 2 times was achieved. Welded joints of large-sized cast-welded billets of beds for high-capacity mills are characterized by high quality. 8 Ref., 5 Figures.
\end{abstract}

$\boldsymbol{K} \boldsymbol{e} \boldsymbol{y} \boldsymbol{w} \boldsymbol{o r d} \boldsymbol{s}:$ electroslag welding, consumable nozzle, large-sized beds, heating, intermediate tempering, machine time reduction

Electroslag welding (ESW) of large-sized metal billets is the most effective and widely applied welding process in manufacturing load-carrying elements of high-capacity machines and installations of mining, metallurgical and other sectors of heavy mechanical engineering [1]. First examples of manufacturing such metal structures of bed type in cast-welded variant were successfully implemented already at the start of ESW introduction at Novo-Kramatorsk Machine-Building Works (NKMZ) [2]. Scale breaker bed was made of four elements (St25L steel, $470 \mathrm{~mm}$ thickness of edges being welded) joined by ESW with wire electrodes. Butt joints were welded by one multielectrode machine of A-395 type in a certain sequence. After welding the bed plate was subjected to total high-temperature treatment
(HTT) (normalizing with tempering). Further on technology and technique of fabrication of metal structures of this type was improved in the directions of application of consumable nozzle (CN) ESW process and method of metered counteraction to welding deformations [3, 4].

In NKMZ welding production the high engineering level of manufacturing cast-welded or roll-welded massive parts is ensured, primarily, due to availability of modern welding equipment and required technological fixtures $[5,6]$, as well as application of high-efficient technological measures developed on the basis of electroslag process investigations [7].

Welded beds are designed to have an O-shape, consisting of individual elements connected predominantly by CN ESW. Bed of 50-62 t weight, consisting of two elements, was welded by one common weld by the schematic shown in Figure 1. Welding of beds of 205-270 t weight,

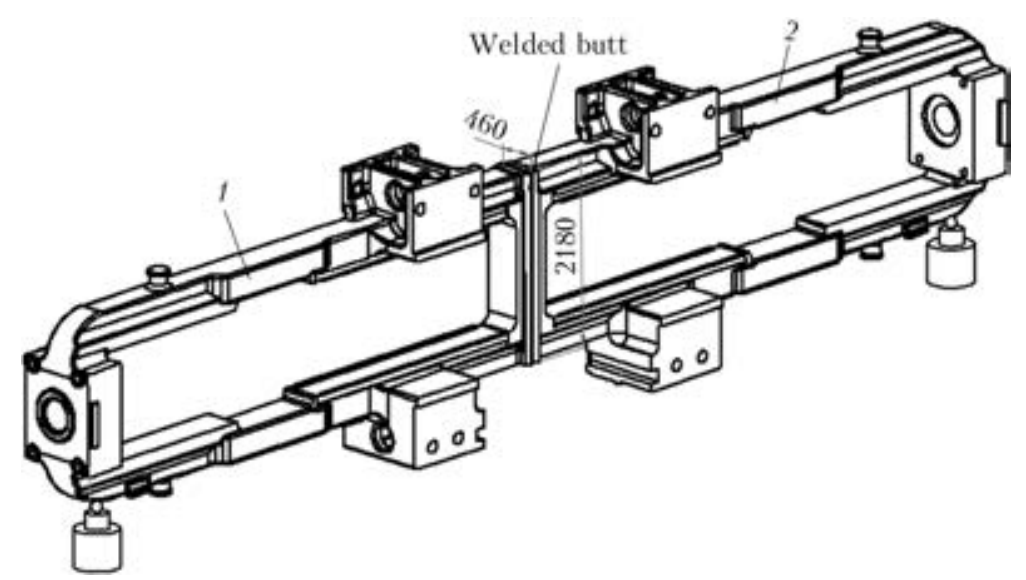

Figure 1. Schematic of assembly of bed elements for single-weld welding: 1 - left; 2 - right element

(c) K.P. SHAPOVALOV, V.A. BELINSKY, S.N. KOSINOV, S.N. LITVINENKO, K.A. YUSHCHENKO, I.I. LYCHKO and S.M. KOZULIN, 2015 


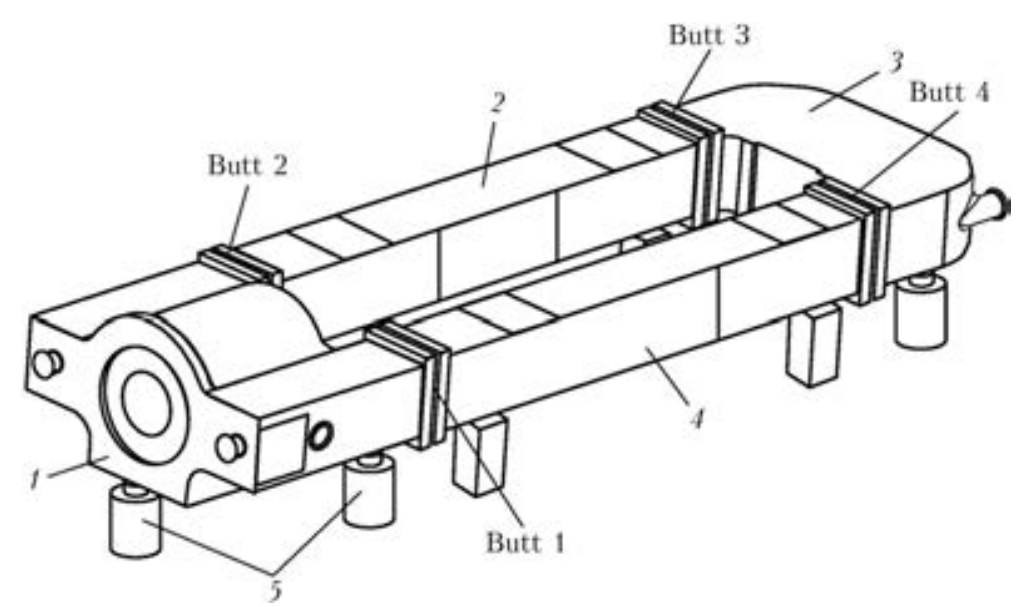

Figure 2. Schematic of assembly of bed elements with four welds: 1 - lower part; 2,4 - middle inserts; 3 - upper part; 5 - supports

consisting of four elements, is usually performed in two steps: on two symmetrically located butts simultaneously (Figure 2).

Equipment available in the assembly-welding section and creative improvement of earlier developed technological measures at realization of specific CN ESW technologies for shop conditions and product range enabled organizing efficient production of such welded metal structures.

Modern technology and technique for $\mathrm{CN}$ ESW of cast-welded beds of different modifications of mill stands was successfully implemented in G.Z. Voloshkevich shop section of thick metal ESW in manufacture of rolling equipment within the framework of a number of large-scale projects on reconstruction of plate mills «2800» of Alchevsk, «2850» of Asha, «2500» of Magnitogorsk Metal Works and at construction of «4300» mill in the town of Rourkela, India.

Guarantee of electroslag process running without forced shutdowns, continuous monitoring of the main parameters of welding mode and subsequent HTT provides the required quality of welded joint metal, and precise allowance for

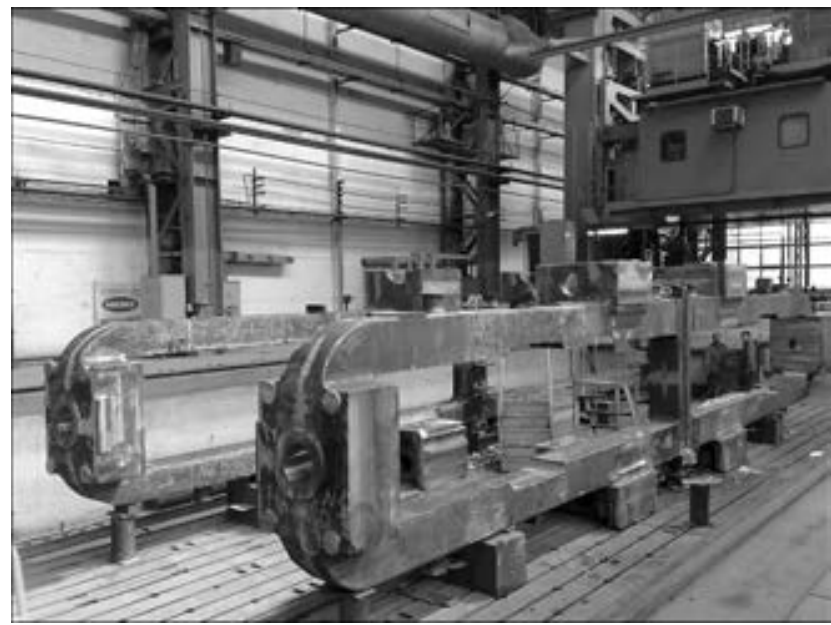

Figure 3. Simultaneous welding of two beds by the schematic in Figure 1 (work in progress) anticipated deformations ensures high accuracy of geometrical dimensions of bed structure after welding and, hence, minimum allowances for final machining. Continuous monitoring of welding modes is indicative of high reliability of maintaining and monitoring the selected parameters: not a single case of forced shutdown of the welding process has been recorded. Displacement of elements being welded was determined by measurement of the distance between center marks made on the base on top and bottom of the butts at $200 \mathrm{~mm}$ on both sides. Proceeding from the results of ultrasonic testing of welded joint metal conducted after HTT, all the beds were found to be fit for further processing.

Unique performance characteristics of the machine for CN ESW of thick metal [5, 6] enabled welding of butt joints of two separate beds (Figure 3) by the schematic in Figure 1 and of two butt joints of the same bed (Figure 4) by the schematic in Figure 2 simultaneously, thus reducing machine time of welding practically 2 times. Altogether four beds were made by the schematic in Figure 1 (butts of $420-460 \times 2200-$

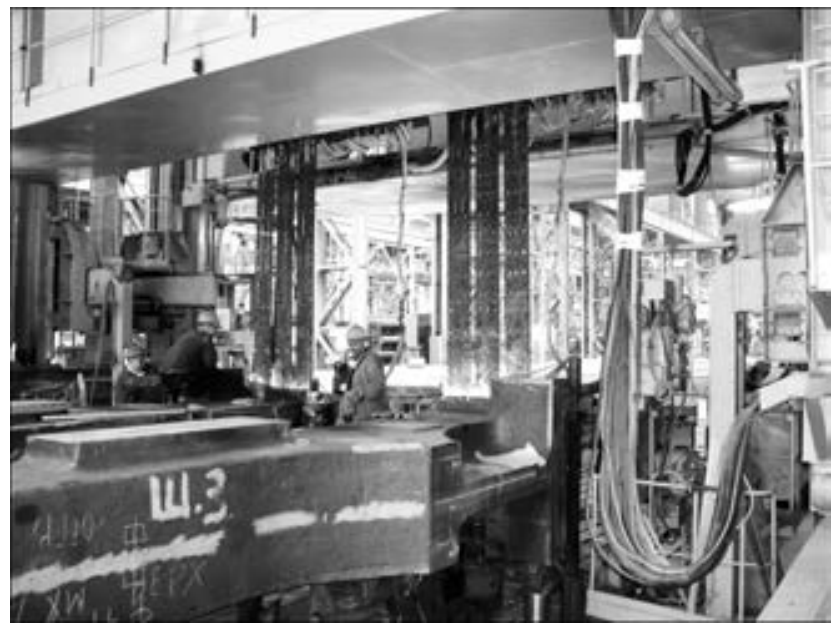

Figure 4. Electroslag welding of two welds by the schematic in Figure 2 (work in progress) 


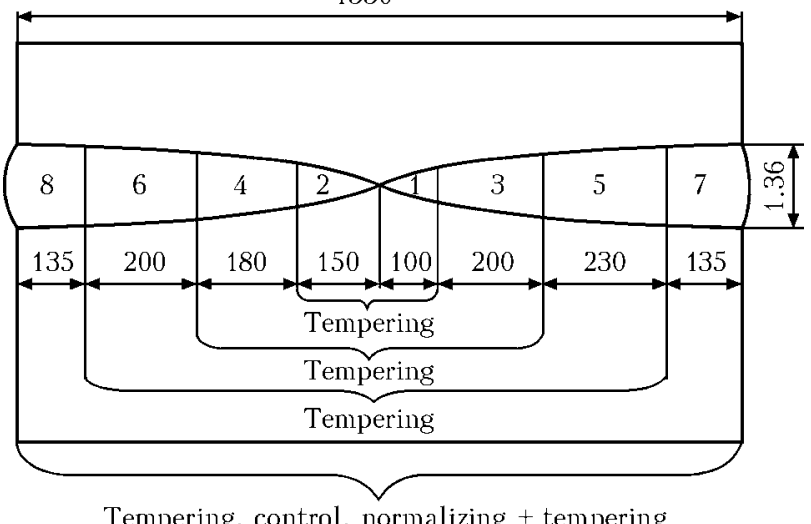

Tempering, control, normalizing + tempering

Figure 5. Sequence of groove filling in the butt and heat treatment of welds in manufacture of the bed with application of automatic SAW [8]

$2380 \mathrm{~mm}$ cross-section) and 14 beds - by the schematic in Figure 2 (butts of 940-1120 × 1040$1250 \mathrm{~mm}$ cross-section). Duration of assemblywelding operations for variant of bed with one weld was 4 days, and for the bed with four welds it was 6 days.

In recent years, some specialists sometimes have had doubts about the priority of ESW application in manufacturing thick metal structures, referring to other welding processes as, for instance, narrow-gap automatic arc welding (AAW) or electron beam welding. Indeed, these processes allow welding up rather large thicknesses, but they are so far applied most often as an exception.

For comparison, we will give some data on manufacturing of a bed of «5000» mill with application of narrow-gap AAW. Bed elements were joined by six welds: a) four welds with butt cross-section of $1060 \times 1060 \mathrm{~mm}$; b) two welds of $1060 \times 1330 \mathrm{~mm}$ cross-section [8]. Butt joint shape and sequence of weld filling are shown in Figure 5. Welding up of four welds (a) was performed simultaneously by four ESAB welding machines, and then welding up of two welds was performed (b). Technology of butt filling with welding wire envisaged the following: preheating and concurrent heating of each butt up to 150$200{ }^{\circ} \mathrm{C}$ (at ESW only heating of the butt beginning is performed); successive deposition of welds in the gap individual sections; bed turning over to fill the opposite section; intermediate tempering of each two opposite sections (see Figure 5) at $580-600{ }^{\circ} \mathrm{C}$. Welds were made with application of a special high-capacity turnover; device for preheating and concurrent heating; other fixture elements to ensure the bed geometrical parameters; immediate intermediate tempering after welding each two opposite sections. Technology of narrow-gap AAW does not have any advantages over ESW in any of the production cycle parameters. For instance, amount of deposited metal for six welds is equal to more than $7000 \mathrm{~kg}(2300 \mathrm{~kg}$ at ESW), while machine time is incomparable at all.

Thus, technique and technology of production of cast-welded large-sized billets for beds of highcapacity rolling mills, based on scientifically grounded application of CN ESW techniques, enables the plant to produce high-efficient competitive products.

1. (1980) Electroslag welding and cladding. Ed. by B.E. Paton. Moscow: Mashinostroenie.

2. Sterenbogen, Yu.A., Pogorelov, V.S. (1956) Electroslag welding of body of scale breaker. Avtomatich. Svarka, 4, 108-114.

3. Paton, B.E., Dudko, D.A., Yushchenko, K.A. et al. (1987) Electroslag welding: Results, problems and prospects of development. Ibid., 5, 32-42.

4. Sushchuk-Slyusarenko, I.I., Lychko, I.I., Koval, I.M. et al. (1968) Producing exact sizes of large-dimensioned bodies in electroslag welding. Ibid., 11, 55-58.

5. Nevidomsky, V.A., Krasilnikov, S.G., Panin, A.D. et al. (2002) New machine for electroslag welding of large parts at JSC «NKMBF». The Paton Welding J., 2, 49-51.

6. Litvinenko, S.N., Shapovalov, K.P., Savchenko, I.S. et al. (2013) Systems of process control and monitoring of conditions - the important factors of quality assurance in electroslag welding of thick metal. Ibid., 12, 39-41.

7. Yushchenko, K.A., Lychko, I.I., SushchukSlyusarenko, I.I. (1999) Effective techniques of electroslag welding and prospects for their application in welding production. In: Welding and Surfacing Rev., Vol. 12, 1-108.

8. Karzov, G.P., Galyatkin, S.N., Varovin, A.Ya. et al. (2009) Automatic submerged-arc welding of elements of superthick structures. Voprosy Materialovedeniya, 3, 357-371

Received 28.05.2015 